\title{
MEDIA SOSIAL DAN PEMBELAJARAN: STUDI EFEKTIVITAS PENGGUNAAN FACEBOOK DALAM PEMBELAJARAN BAHASA INGGRIS
}

\author{
Euis Meinawati'; Rifari Baron² \\ 1 Universitas Bina Sarana Informatika Jakarta, Indonesia. \\ 2Universitas Indraprasta PGRI Jakarta, Indonesia. \\ 1euis.eum@bsi.ac.id, 2rifari.baron@unindra.ac.id
}

\begin{abstract}
Abstrak
Penelitian ini adalah kajian tentang efektivitas penggunaan media sosial, yaitu facebook, untuk meningkatkan kemampuan mahasiswa dalam menulis deskriptif berbahasa Inggris. Penelitian ini adalah penelitian tindakan kelas. Data dikumpulkan dari observasi, dokumentasi, dan tes. Hasil analisis data menunjukkan bahwa: 1) proses pembelajaran menulis deskriptif bahasa Inggris menggunakan facebook lebih bervariasi dan menyenangkan, dan 2) ada peningkatan kemampuan menulis deskriptif bahasa Inggris yang ditandai dari peningkatan hasil tes. Hal tersebut terlihat pada hasil nilai rata-rata pre-test sebesar 66.25 , dan hasil rata-rata post-test sebesar 80.15. Dengan demikian dapat disimpulkan bahwa facebook dapat dimanfaatkan untuk meningkatkan hasil belajar dalam pembelajaran bahasa Inggris.
\end{abstract}

Kata kunci: Menulis Bahasa Inggris, Facebook, Menulis Deskriptif, Media Pembelajaran

\begin{abstract}
This research is a study of the effectiveness of using social media, namely Facebook, to improve students' ability to write descriptive English. This research is a classroom action research. The data are taken from observation, documentation, and tests. The results of data analysis show that: 1) the process of learning descriptive English using Facebook is more varied and enjoyable, and 2) there is an increase in students' ability to write descriptive English which is marked by an increase in test results. This can be seen from the average of the pre-test and pos-test score, which is 66.25 and 80.15 respectively. Thus it can be concluded that Facebook can be used to improve learning outcomes in learning English.
\end{abstract}

Keywords: English writing, Facebook, Descriptive Writing, Learning Media 


\section{PENDAHULUAN}

Proses pembelajaran bahasa lebih baik diberikan pada saat masih anak-anak agar mereka mampu mengucapkan dan menguasai gramatikal struktur bahasa seperti native speaker. Sehingga kompetensi yang ada dalam bahasa Inggris mampu dikuasai. Kemampuan ini mencakup membaca, menulis, mendengarkan dan berbicara. Mendengarkan dan membaca termasuk kategori kemampuan reseptif aktif. Sedangkan berbicara dan menulis disebut kemampuan produktif aktif. Untuk membaca dan menulis biasanya menggunakan media visual. Karena persyaratan dari penguasaan tersebut meliputi kaidah gramatikal, fonologi, morfologi, konteks kalimat dan sintaksis yang baik dan benar berdasarkan aturan yang telah ditetapkan. Meskipun pada kemampuan tertentu hal itu tidak begitu esensial. Tentunya menulis disini harus mengikuti kaidah penulisan dalam bahasa Inggris yang baik dan benar. Akan tetapi, kenyataan yang ada sekarang bahwa mahasiswa belum mampu menulis dengan baik, pengajaran menulis (writing) bahasa Inggris belum menunjukkan hasil yang maksimal, pemanfaatan kemajuan teknologi masih rendah untuk proses pembelajaran, dan sebagainya.

Kendala yang muncul dalam proses pembelajaran writing bukan saja sarana yang dimiliki mahasiswa kurang lengkap seperti kamus, buku referensi, dan sebagainya. Mahasiswa tidak mau mencari referensi lain karena sudah ketergantungan pada slide yang disusun oleh komisi Bahasa Inggris Universitas Bina Sarana Informatika Jakarta. Mereka menganggap bahwa slide tersebut cukup untuk belajar tentang menulis. Penyediaan slide hanya untuk membantu proses pembelajaran di kelas karena proses belajar mengajar (PBM) yang berlangsung di BSI sudah menggunakan multimedia. Akan tetapi hal tersebut disalahartikan dan mahasiswa pun menganggap slide merupakan sumber belajar utama. Mahasiswa tidak mau mencari sumber belajar yang lain. Jadi mahasiswa lebih menyukai proses belajar dengan metode ceramah (teacher - centered) daripada student - centered. Selain itu, hasil pengamatan yang dilakukan peneliti telah menunjukkan 
bahwa setiap proses belajar berlangsung, seringkali mahasiswa menggunakan telepon genggam di kelas. Jadi tingkat keinginan mahasiswa untuk belajar menulis masih rendah.

Permasalahan pembelajaran menulis deskriptif yaitu mahasiswa sulit mengembangkan imajinasi dari gambar atau informasi yang diberikan, mahasiswa kesulitan berdiskusi dengan rekan sejawat, mahasiswa lebih menyukai menggunakan perangkat telepon genggam daripada serius menulis. Dalam belajar menulis deskripsi dibutuhkan adanya ketelitian, kepaduan, keruntutan dan kelogisan antara kalimat satu dengan kalimat yang lain, antara paragraf dengan paragraf berikutnya sehingga akan membentuk sebuah karangan yang baik dan utuh. Dalam belajar menulis banyak ragam yang bisa dipelajari seperti menulis deskripsi, argumentasi, eksposisi, dan sebagainya. Menulis deskripsi merupakan jenis tulisan yang menggambarkan sesuatu sehingga si pembaca dapat merasakan apa yang dimaksudkan oleh penulis. Namun, mahasiswa masih sulit mengembangkan imajinasi mereka dalam membuat tulisan deskripsi.

Oleh karena itu, hasil pengamatan selama satu semester tahun ajaran 2017/2018 tersebut menunjukkan bahwa banyak mahasiswa yang memainkan telepon genggam selama proses belajar berlangsung seperti melakukan chatting baik di facebook, twitter, yahoo, WA, ataupun sekejar menonton youtube. Padahal selama belajar satu semester telah ada perjanjian kuliah untuk tidak memainkan telepon. Oleh karena itu, peneliti beranggapan bahwa kondisi tersebut dapat dimanfaatkan untuk meningkatkan kenyamanan belajar mahasiswa yang berlangsung di kelas, dan bisa berlanjut di luar kelas.

Salah satu kreatifitas yang dilakukan untuk penelitian ini adalah menfaatkan social media untuk mendukung proses pembelajaran dan pengajaran menulis deskriptif. Seperti dalam penelitian Bicen, Sadıkoglu, \& Sadıkoglu (2015) telah mengidentifikasi situs jejaraing sosial untuk pembelajaran Bahasa Inggris. Dalam penelitiannya ditemukan kekhawatiran 
mahasiswa untuk berkomunikasi. Sedangkan pada proses pembelajaran menulis akan memiliki konsep berbeda. Karena yang diutamakan adalah kemampuan penggunaan tata Bahasa. Sedangkan pada penelitian Ahmad Zaki \& Md Yunus (2015) menggunakan perangkat seluler untuk diskusi dalam pembelajaran menulis akademik. Dari hasil penelitian ditemukan bahwa perangkat mobile memiliki pengaruh sangat tinggi terhadap hasil menulis akademik. Dari kedua penelitian tersebut dipahami bahwa teknologi memiliki peranan penting dalam kegiatan rutin mahasiswa. Teknologi telah menjadi bukti kehidupan sebagai media komunikasi dalam kehidupan sehari-hari yang mempengaruhi pembelajaran bahasa. Seperti sosial media (Facebook, Twitter, berkirim pesan, Second Life, email) telah memberikn peran ganda untuk proses pembelajaran. Dalam penelitian Ponnudurai \& Jacob (2014), ada korelasi positif antara menulis online melalui Facebook dan tingkat kecemasan, simpulan yang dihasilkan bahwa ada sikap positif terhadap penggunaan Facebook dalam pembelajaran.

Berdasarkan paparan masalah, tujuan penelitian adalah untuk mengetahui peningkatan kemampuan menulis deskriptif bahasa Inggris menggunakan facebook. Rumusan masalah penelitian ini, yaitu: (1) bagaimana implementasi facebook dalam proses pembelajaran dan pengajaran menulis deskriptif bahasa Inggris? Dan (2) bagaimana peningkatan kemampuan menulis deskriptif bahasa Inggris menggunakan facebook?

\section{LANDASAN TEORI}

\section{Menulis Deskriptif Berbahasa Inggris}

Pengertian menulis dapat dipahami dari berbagai aspek seperti dari aspek sosial, menurut Hamp-Lyons \& Kroll menulis adalah suatu aktivitas yang terjadi berdasarkan konteks, untuk mendapatkan tujuan, dan memberikan bentuk tulisan yang ditujukan kepada pembaca. Pendapat yang sama dari Sperling menjelaskan bahwa menulis seperti 
bahasa pada umumnya, yang berarti melakukan aktivitas secara sosial dan budaya serta secara individu dan tujuan sosial (Weigle, 2002).

Dalam pola menulis, deskripsi dan narasi selalu saling berhubungan. Karena seseorang tidak pernah menggambarkan sesuatu tanpa dihubungkan dengan yang lain, khususnya dalam bercerita atau narasi. Dan sebaliknya seseorang jarang menceritakan sesuatu tanpa memasukkan deskripsi. Sebuah narasi bergerak melalui waktu; deskripsi biasanya bergerak melalui ruang (Brandon \& Brandon, 2011). Deskripsi adalah penggunaan kata-kata untuk menggambarkan penampilan dan sesuatu. Dalam membuat tulisan deskripsi, tergantung pada anda bagaimana ingin menggunakan materi atau subyek, tulisan deskripsi cenderung objektif dan subjektif. Menulis deskripsi objektif efektif ketika subyek yang disajikan jelas dan secara langsung seperti tanpa sentuhan emosi. Jika anda menulis tentang hati atau perasaan, karakter komputer, atau renovasi fasilitas manufaktur, tulisan deskripsi anda akan menjelaskan fitur yang lebih spesifik tentang hal tersebut. Menulis deskripsi subjektif berhubungan dengan kejelasan cerita dan langsung, tetapi menyampaikan perasaan subjek tersebut. Karena sebagian besar ungkapan cerita melibatkan pandangan pribadi, bahkan ketika menggambarkan juga didukung oleh analisis. Deskripsi subjektif (sering disebut deskripsi emosional) karena memiliki tingkatan gambaran yang lebih luas daripada deskripsi objektif. Paragraf deskripsi bisa dikombinasikan antara deskripsi subjektif dan objektif (Brandon \& Brandon, 2011). Deskripsi subjektif seperti menggunakan imaginasi yang lebih luas, bahasa figuratif, dan kaya akan hubungan kata daripada deskripsi objektif.

Menulis deskripsi merupakan salah satu teknik dalam percakapan dari teknik ini penulis menemukan pola untuk mmebuat suatu tulisan. Kita menggambarkan apa tujuan dari tulisan kita baik tentang orang, tempat, dan sebagainya. Menulis deskripsi yang baik mampu 
menciptakan rasa, dan menggunakan hal-hal nyata serta lebih khusus menggambarkan tentang seperti cahaya, bunyi, rasa, serta sentuhan supaya dapat memberikan pengalaman yang sama dengan pembaca atau pendengar. Menulis dengan pola deskripsi sama dengan narasi. Perbedaan antara narasi dan deskripsi pada penggunaan langkah-langkah menulis narasi. Sedangkan deskripsi focus kepada rasa dan penciptaan kata (Sova, 2004).

Berdasarkan uraian di atas, dapat disimpulkan bahwa menulis deskripsi adalah penuangan ide yang melukiskan suatu objek sehingga pembaca seolah-olah melihat, mendengar, merasakan hal-hal yang ditulis penulis. Menulis paragraf deskripsi dapat menumbuhkan kreativitas siswa dalam menggambarkan hal-hal konkret sebelum menuliskan halhal yang akan abstrak. Paragraf deskripsi adalah suatu paragraf yang didalamnya memberikan perincian yang mendetail tentang objek sehingga seakan-akan pembaca melihat, mendengar atau mengalami langsung tentang objek tersebut. Tujuan dari tulisan deskripsi adalah menciptakan gambaran objek kepada pembaca agar seolah-olah melihat sendiri objek yang digambarkan penulis. Objek paragraf deskripsi dapat berupa benda, orang, peristiwa, suasana dan lainnya.

\section{Facebook sebagai Media Pembelajaran}

Integrasi teknologi digital dalam pembelajaran diharapkan dapat berperan sebagai alat dedaktik, yaitu sebagai alat yang dapat memicu pemahaman konseptual siswa tentang objek yang dipelajari dan bukan sebaliknya (Putrawangsa \& Uswatun, 2018). Oleh karena itu, memahami prinsip dan faktor yang mempengaruhi efektivitas penggunaan teknologi digital, seperti Facebook, dalam pembelajaran adalah krusial untuk menghindari penggunaan yang tidak tepat yang dapat memberikan dampak buruk bagi siswa (Putrawangsa \& Uswatun, 2018).

Dalam konteks pembelajaran, Facebook adalah jejaring sosial yang dapat membantu pelajar untuk mentransfer ide-idenya dan 
pandangannya kepada teman-teman sekelasnya dan pertukaran ide dan informasi di antara mereka sendiri. Sejumlah riset menyebutkan bahwa penggunaan Facebook dalam proses pendidikan membantu mengembangkan keterampilan bahasa di kalangan siswa dan mengaktifkan peran positif mereka dalam partisipasi aktif dengan teman sekelas mereka. Stern dan Taylor menunjukkan bahwa sebagian besar siswa tidak memiliki pengalaman negatif di Facebook (Al-Hersh \& Muflih, 2014). Dari pemahman konsep tersebut dapat dijelaskan bahwa facebook sebagai alat jejaring sosial telah memberikan kemudahan dan menyenangkan untuk proses pembelajaran bahasa.

Melalui literasi digital, siswa membuat jejaring dan belajar untuk mencocokkan media sosial dengan informasi yang mereka hasilkan dan audiens yang mereka tuju. Sabatino (2014) mengusulkan integrasi permainan dan komposisi sebagai cara untuk mengembangkan praktik menulis siswa. Dalam artikel ini, saya menunjukkan bagaimana bidang komposisi seperti keterlibatan, penyelesaian masalah, kolaborasi, dan audiens terhubung ke dunia game Facebook.

Dengan demikian dapat dipahami bahwa kreatifitas dalam pengajaran menulis deskriptif dapat dilakukan melalui pemanfaatan teknologi yang sering digunakan oleh kebanyakan mahasiswa, seperti facebook. Jejaring sosial ini memberikan kesempatan mahasiswa untuk belajar menulis lebih luas karena dapat terhubungan kesemua lini kehidupan sosial masyarakat di dunia. Facebook memberikan media belajar menulis. Setiap orang dapat dengan mudah mengakses atau membuka facebook dimanapun tanpa harus menggunakan perangkat laptop. Saat ini telepon genggam telah memberikan kemudahan untuk mengakses aplikasi facebook. Media ini dapat digunakan sebagai kelompok diskusi untuk permasalahan ataupun proses pembelajaran menulis bahasa Inggris, khususnya pembelajaran menulis deskriptif. 


\section{METODE}

Pendekatan penelitian yang digunakan adalah metode penelitian tindakan. Tahapan dalam penelitian tindakan ini menggunakan model Elliot. Tindakan yang telah dilaksanakan sebanyak dua siklus. Sampel penelitian adalah mahasiswa semester II tahun ajaran 2017/2018 sebanyak 20 mahasiswa. Teknik pengumpulan data yang digunakan adalah tes, observasi, dan dokumentasi. Proses validitas data penelitian adalah kredibilitas, transferabilitas, dependabilitas dan konfirmabilitas. Penelitian ini juga melibatkan kolaborator sebagai pembanding untuk menganalisis data. Proses kegiatan analisis data dilakukan berdua dengan kolaborator. Sedangkan untuk mengetahui efektifitas penggunaan facebook dalam pembelajaran menulis deskriptif bahasa Inggris menggunakan hasil tes, yaitu pre-test dan post-test. Selain itu, observasi dilakukan untuk mengamati proses pembelajaran selama tindakan. Proses tindakan dikatakan berhasil ketika setiap mahasiswa telah mencapai minimal nilai 70 dan nilai rata-rata kelas mencapai minimal 80.

\section{HASIL DAN PEMBAHASAN}

\section{Implementasi Facebook Dalam Proses Pembelajaran dan Pengajaran Menulis Deskriptif Bahasa Inggris}

Kegiatan tindakan untuk pembelajaran menulis deskriptif dilaksanakan selama 2 siklus, dimana setiap siklus terdiri dari tiga pertemuan. Temuan data diperoleh dari dokumen kegiatan pembelajaran setiap pertemuan dan observasi atau pengamatan terhadap aktivitas mahasiswa dan dosen selama tindakan berlangsung. Data yang sudah terkumpul kemudian dianalisis bersama dengan kolaborator sehingga hasil penarikan kesimpulan penelitian ini lebih terjaga tingkat kehandalannya. Karena peneliti menentukan simpulan juga disesuaikan dengan hasil analisis dari kolaborator.

Implementasi facebook dalam proses belajar mengajar menulis 
deskriptif bahasa Inggris selama dua siklus disimpulkan memberikan perubahan terhadap sikap mahasiswa dalam belajar di kelas. Mahasiswa mengalami peningkatan yang cukup signifikan dari pertemuan pertama sampai pertemuan ketiga setiap siklus. Hal ini dapat dilihat dari analisis data dokumen dari pengamatan aktivitas belajar mahasiswa di kelas dan juga aktivitas dosen selama proses tindakan. Analisis data aktivitas mahasiswa oleh peneliti dan kolaborator sedangkan analisis aktivitas dosen dinilai oleh kolaborator. Hasil observasi terhadap aktivitas belajar tersebut memperkuat analisis data untuk mengetahui implementasi facebook selama belajar menulis deskriptif bahasa Inggris. Aktivitas mahasiswa cenderung mengalami perubahan dan dosen selalu melakukan perbaikan untuk meningkatkan proses pembelajaran yang lebih berkualitas.

Tabel 1. Rekapitulasi Hasil Penilaian Aktivitas Dosen Selama Tindakan

\begin{tabular}{|c|c|c|c|c|c|c|c|}
\hline \multirow{2}{*}{ No } & \multirow{2}{*}{ Aktivitas yang diamati } & \multicolumn{3}{|c|}{ Siklus $1(\%)$} & \multicolumn{3}{|c|}{ Siklus $2(\%)$} \\
\hline & & 1 & 2 & 3 & 1 & 2 & 3 \\
\hline 1 & $\begin{array}{l}\text { Dosen melakukan kegiatan pembuka } \\
\text { dengan runut }\end{array}$ & 60 & 60 & 80 & 80 & 100 & 100 \\
\hline 2 & $\begin{array}{l}\text { Dosen memberikan warming up pada } \\
\text { setiap pertemuan }\end{array}$ & 100 & 100 & 100 & 100 & 100 & 100 \\
\hline 3 & $\begin{array}{l}\text { Dosen mereview materi yang telah } \\
\text { dipelajari yang dikaitkan dengan } \\
\text { tujuan pembelajaran yang ingin } \\
\text { dicapai }\end{array}$ & 80 & 80 & 80 & 80 & 80 & 100 \\
\hline 4 & $\begin{array}{l}\text { Dosen menjelaskan materi dengan } \\
\text { jelas }\end{array}$ & 100 & 80 & 100 & 100 & 100 & 100 \\
\hline 5 & $\begin{array}{l}\text { Dosen menggunakan facebook_dengan } \\
\text { tepat dan terarah }\end{array}$ & 60 & 80 & 80 & 100 & 100 & 80 \\
\hline 6 & $\begin{array}{l}\text { Dosen memfasilitas proses diskusi di } \\
\text { kelas dengan baik }\end{array}$ & 80 & 100 & 100 & 100 & 100 & 100 \\
\hline 7 & $\begin{array}{l}\text { Dosen selalu melakukan tanya jawab } \\
\text { di kelas }\end{array}$ & 100 & 100 & 100 & 100 & 100 & 100 \\
\hline 8 & $\begin{array}{l}\text { Dosen memberikan timbal balik } \\
\text { terhadap latihan yang dikerjakan } \\
\text { mahasiswa }\end{array}$ & 60 & 60 & 100 & 80 & 100 & 100 \\
\hline 9 & $\begin{array}{l}\text { Dosen melibatkan mahasiswa dalam } \\
\text { evaluasi hasil belajar }\end{array}$ & 80 & 100 & 100 & 100 & 100 & 100 \\
\hline 10 & $\begin{array}{l}\text { Kegiatan penutup dilakukan dengan } \\
\text { tepat dan jelas }\end{array}$ & 100 & 100 & 100 & 100 & 100 & 100 \\
\hline
\end{tabular}


Tabel 1 menunjukkan aktivitas dosen selama kegiatan pembelajaran berbantuan facebook. Berdasarkan tabel tersebut dapat disimpulkan bahwa aktivitas dosen selama proses mengajar sudah sangat baik dan optimal. Hal ini dapat dilihat dari peningkatan persentase yang telah diberikan oleh kolaborator.

Adapun aktivitas mahasiswa selama belajar tergambar pada tabel 2. Berdasarkan tabel 2 dapat disimpulkan bahwa aktivitas mahasiswa dari pertemuan awal sampai pertemuan ketiga setiap siklus cenderung mengalami peningkatan yang cukup baik. Jadi, mahasiswa sudah mampu menggunakan facebook untuk belajar menulis deskriptif. Keberhasilan penerapan facebook dalam pembelajaran menulis deskriptif bahasa Inggris dapat dianalisis dari dokumen catatan harian mahasiswa. Secara keseluruhan disimpulkan bahwa mahasiswa memberikan sikap positif terhadap penggunaan facebook selama proses menulis deskriptif bahasa Inggris. Mereka sudah mampu memanfaatkan facebook dengan sangat baik selama proses belajar di kelas dan di luar kelas. Dengan demikian bisa dikatakan bahwa penerapan media sosial tersebut menghasilkan pembelajaran menulis deskriptif yang cukup memuaskan terhadap peningkatan kemampuan menulis deskriptif bahasa Inggris.

Tabel 2. Rekapitulasi Hasil Penilaian Aktivitas Mahasiswa Selama Tindakan

\begin{tabular}{|c|c|c|c|c|c|c|c|}
\hline \multirow{2}{*}{ No } & \multirow{2}{*}{ Aktivitas yang diamati } & \multicolumn{3}{|c|}{ Siklus 1 (\%) } & \multicolumn{3}{|c|}{ Siklus $2(\%)$} \\
\hline & & 1 & 2 & 3 & $\mathbf{1}$ & 2 & 3 \\
\hline 1 & $\begin{array}{l}\text { Mahasiswa mampu memahami } \\
\text { tujuan pembelajaran yang telah } \\
\text { dijelaskan oleh dosen }\end{array}$ & 30 & 45 & 45 & 60 & 75 & 95 \\
\hline 2 & $\begin{array}{l}\text { Mahasiswa mampu menyelesaikan } \\
\text { kegiatan dalam warming up }\end{array}$ & 30 & 50 & 70 & 75 & 85 & 100 \\
\hline 3 & $\begin{array}{l}\text { Mahasiswa terlibat aktif dalam } \\
\text { diskusi kelompok selama } \\
\text { penggunaan facebook }\end{array}$ & 50 & 50 & 70 & 75 & 85 & 90 \\
\hline 4 & $\begin{array}{l}\text { Mahasiswa mampu menyelesaikan } \\
\text { tugas menulis dengan tepat waktu }\end{array}$ & 45 & 55 & 70 & 80 & 95 & 95 \\
\hline 5 & Mahasiswa mampu memanfaatkan & 50 & 70 & 70 & 85 & 90 & 100 \\
\hline
\end{tabular}


Meinawati, E., \& Baron, R. (2019). MEDIA SOSIAL DAN PEMBELAJARAN: STUDI EFEKTIVITAS PENGGUNAAN FACEBOOK DALAM PEMBELAJARAN BAHASA INGGRIS. Jurnal Tatsqif, 17(1), 34-51.

\begin{tabular}{|c|c|c|c|c|c|c|c|}
\hline & $\begin{array}{l}\text { facebook diluar kelas untuk } \\
\text { menyelesaikan tugas menulis }\end{array}$ & & & & & & \\
\hline 6 & $\begin{array}{l}\text { Mahasiswa bisa memberikan } \\
\text { penilaian terhadap hasil tulisan } \\
\text { mahasiswa di facebook }\end{array}$ & 55 & 55 & 65 & 70 & 80 & 90 \\
\hline 7 & $\begin{array}{l}\text { Mahasiswa melakukan perbaikan } \\
\text { tulisan yang sudah diberikan koreksi } \\
\text { oleh dosen dan rekan sejawat }\end{array}$ & 50 & 65 & 70 & 70 & 85 & 95 \\
\hline 8 & $\begin{array}{l}\text { Mahasiswa mampu melakukan } \\
\text { refleksi diri selama proses evaluasi } \\
\text { pembelajaran di kelas }\end{array}$ & 55 & 60 & 75 & 75 & 80 & 90 \\
\hline 9 & $\begin{array}{l}\text { Mahasiswa mampu memberikan } \\
\text { masukan terhadap peningkatan } \\
\text { penggunaan facebook disetiap akhir } \\
\text { pembelajaran }\end{array}$ & 50 & 60 & 80 & 80 & 95 & \\
\hline 10 & $\begin{array}{l}\text { Mahasiswa mampu memahami } \\
\text { pembelajaran dengan baik }\end{array}$ & 60 & 60 & 80 & 85 & 90 & 100 \\
\hline
\end{tabular}

Berdasarkan pada rujukan teori yang telah dipaparkan, proses pembelajaran menulis deskriptif melalui facebook memberikan tahapan yang cukup mudah bagi mahasiswa. Mereka juga memiliki perasaan senang ketika proses belajar berlangsung.

Adapun aktivitas menulis deskriptif yang dilakukan mahasiswa melalui facebook dipaparkan pada tabel 3. Terdapat empat tahapan menulis, yaitu brainstorming, membuat aoutline, membuat draft tulisan, dan merevisi tulisan. Masing-masing tahapan tersebut secara detait ditunjukkan pada tabel 3.

Tabel 3. Langkah Pembelajaran Menulis Deskriptif Menggunakan Facebook

\begin{tabular}{|c|c|c|c|}
\hline $\begin{array}{l}\text { Tahapan } \\
\text { Menulis }\end{array}$ & $\begin{array}{c}\text { Aktivitas } \\
\text { Diskusi }\end{array}$ & $\begin{array}{c}\text { Aktivitas } \\
\text { Menulis }\end{array}$ & $\begin{array}{l}\text { Aktivitas } \\
\text { Membaca }\end{array}$ \\
\hline Brainstorming & $\begin{array}{l}\text { Mengenalkan } \\
\text { mahasiswa ke } \\
\text { fitur-fitur } \\
\text { facebook dan } \\
\text { proses diskusi } \\
\text { melalui facebook }\end{array}$ & $\begin{array}{l}\text { Memahami topik } \\
\text { dengan tepat }\end{array}$ & $\begin{array}{l}\text { Membaca } \\
\text { beberapa } \\
\text { referensi untuk } \\
\text { mengembangan } \\
\text { topik dan ide } \\
\text { tulisan }\end{array}$ \\
\hline $\begin{array}{l}\text { Membuat } \\
\text { outline }\end{array}$ & $\begin{array}{l}\text { Dosen dan } \\
\text { mahasiswa } \\
\text { memberikan }\end{array}$ & $\begin{array}{l}\text { Mengembangkan } \\
\text { thesis statement } \\
\text { dan menulis }\end{array}$ & $\begin{array}{l}\text { Membaca dengan } \\
\text { seksama untuk } \\
\text { menemukan }\end{array}$ \\
\hline
\end{tabular}


Meinawati, E., \& Baron, R. (2019). MEDIA SOSIAL DAN PEMBELAJARAN: STUDI EFEKTIVITAS PENGGUNAAN FACEBOOK DALAM PEMBELAJARAN BAHASA INGGRIS. Jurnal Tatsqif, 17(1), 34-51.

\begin{tabular}{llll}
\hline & $\begin{array}{l}\text { timbal balik } \\
\text { secara langsung } \\
\text { di kelas dan } \\
\text { berlanjut di luar } \\
\text { kelas melalui } \\
\text { facebook. }\end{array}$ & $\begin{array}{l}\text { sesuai dengan } \\
\text { topik yang } \\
\text { dilengkapi } \\
\text { dengan kalimat } \\
\text { pendukung }\end{array}$ & $\begin{array}{l}\text { informasi yang } \\
\text { tepat dan } \\
\text { menganalisis } \\
\text { informasi } \\
\text { tersebut sehingga } \\
\text { tepat bagi proses } \\
\text { menulis }\end{array}$ \\
$\begin{array}{llll}\text { Membuat draf } \\
\text { tulisan }\end{array}$ & $\begin{array}{l}\text { Diskusi di kelas } \\
\text { dan memberikan } \\
\text { penilaian } \\
\text { terhadap draf } \\
\text { yang sudah } \\
\text { dibuat }\end{array}$ & $\begin{array}{l}\text { Proses membuat } \\
\text { draf dengan } \\
\text { tepat dan } \\
\text { melakukan sitasi }\end{array}$ & $\begin{array}{l}\text { mengecek } \\
\text { kembali validitas } \\
\text { referensi yang } \\
\text { digunakan untuk } \\
\text { mengembangkan } \\
\text { tulisan }\end{array}$ \\
Merevisi & & & $\begin{array}{l}\text { Membaca ulang } \\
\text { dulisan dengan }\end{array}$ \\
& & Merevisi tulisan & yang telah \\
diberikan & penilaian & \\
\hline
\end{tabular}

\section{Peningkatan Kemampuan Menulis Deskriptif Bahasa Inggris} Menggunakan Facebook

Peningkatan kemampuan menulis deskriptif bahasa Inggris diperoleh melalui hasil tes yang diberikan sebelum kegiatan tindakan dan sesudah tindakan pada setiap siklus. Adapun hasil tes dari setiap individu mahasiswa terlihat pada grafik di bawah ini;

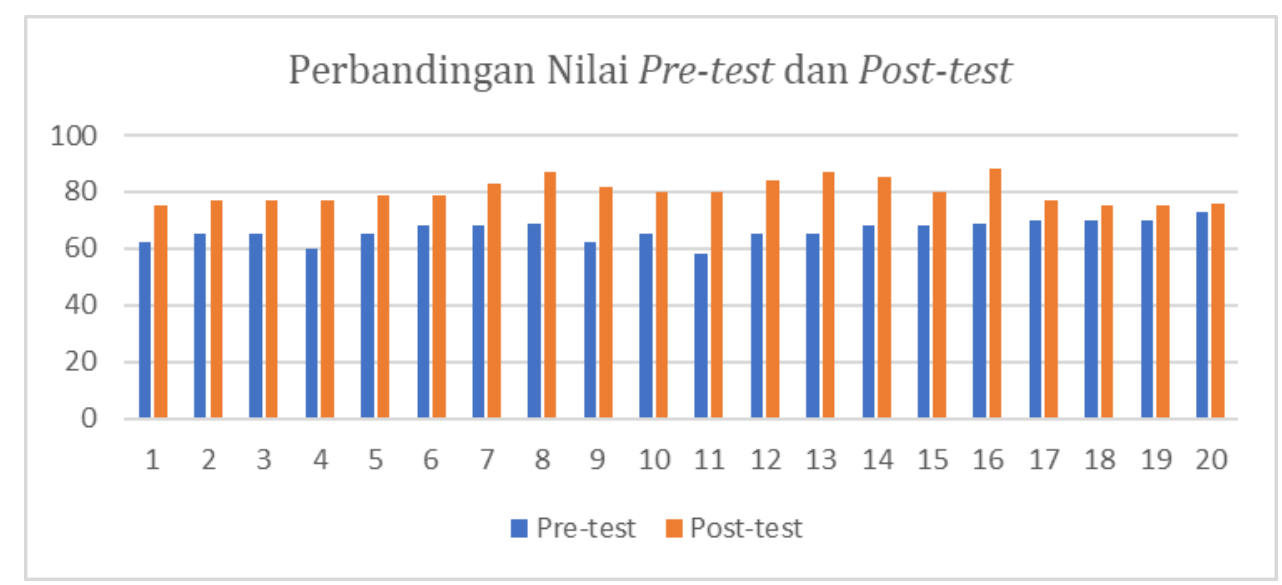

Grafik 1. Perbandingan nilai tes menulis deskriptif bahasa Inggris

Dari garik 1 diketahui bahwa setiap mahasiswa memiliki perkembangan nilai yang cukup baik. Hasil pre-test masih rendah dan 
setelah diberikan pembelajaran maksimal di kelas dan di luar kelas melalui forum diskusi facebook, mahasiswa menunjukkan peningkatan nilai yang sangat baik.

Adapun hasil perhitungan statistik deskriptif terlihat pada tabel 3. Pada tabel 3 disimpulkan bahwa nilai rata-rata kelas yang diperoleh dari kegiatan tindakan ini yaitu pada pre-test sebesar 66.25, dan hasil rata-rata post-test sebesar 80.15. Ada peningkatan point yang cukup baik dari tes awal ke tes akhir. Nilai terendah pada pretest sebesar 58 dan nilai tertinggi sebesar 73. Hal ini berbeda dengan nilai terendah dari hasil post-test sebesar 75 dan nilai tertinggi sebesar 88. Perolehan nilai yang cukup signifikan dari hasil implementasi diskusi melalui facebook. Peningkatan kemampuan menulis deskriptif bahasa Inggris menggunakan facebook dipahami pula dari hasil nilai-nilai latihan yang telah dianalisis oleh dosen. Hasil analisis data disimpulkan bahwa nilai individu mahasiswa mengalami peningkatan yang cukup baik dari pertemuan pertama sampai pertemuan ketiga pada setiap siklus, seperti yang terlihat pada grafik berikut ini;

Tabel 3. Hasil perhitungan nilai tes menulis deskriptif

\begin{tabular}{lrr}
\hline \multicolumn{1}{c}{ Keterangan } & Pre-test & Post-test \\
\hline Nilai Rata-rata & 66.25 & 80.15 \\
Modus & 65 & 77 \\
Minimum & 58 & 75 \\
Maksimum & 73 & 88 \\
Varian & 14.092 & 18.123 \\
Standar Deviasi & 3.754 & 4.258 \\
\hline
\end{tabular}




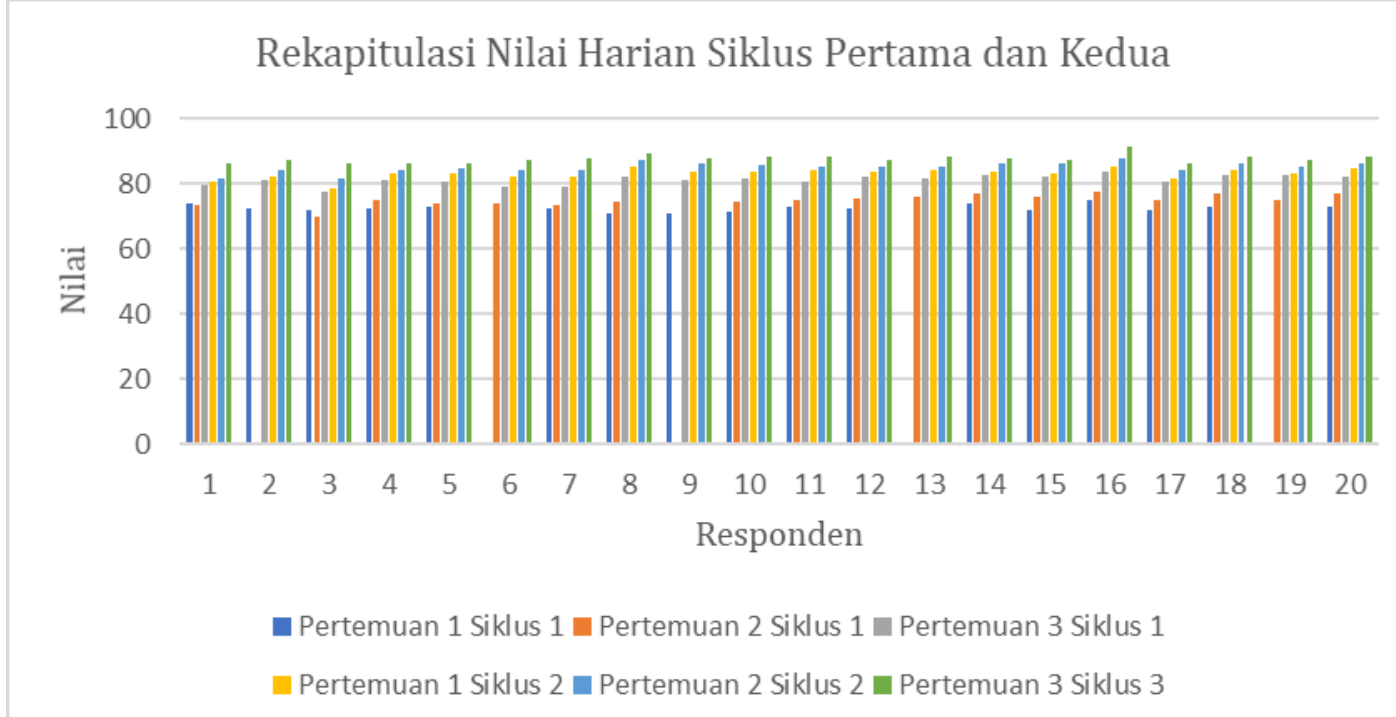

Grafik 2. Rekapitulasi nilai latihan menulis deskriptif bahasa Inggris

Grafik 2 disimpulkan bahwa nilai latihan menulis deskriptif bahasa Inggris mahasiswa dari pertemuan pertama sampai ketiga pada siklus pertama cenderung mengalami peningkatan yang cukup stabil. Dari hasil analisis ada 85\% dari jumlah mahasiswa yang nilai latihannya mengalami kenaikan cukup baik. Begitupun sebaliknya bahwa pada siklus kedua menunjukkan 100\% mahasiswa selalu mengalami peningkatan nilai latihan. Jadi disimpulkan bahwa nilai latihan mahasiswa dari siklus pertama dan siklus kedua yang telah mengalami peningkatan secara konsisten sebesar $85 \%$.

\section{Facebook dan pembelajaran Bahasa Inggris}

Penelitian ini menemukan bahwa media sosial facebook dapat dimanfaatkan sebagai media pembelajaran untuk meningkatkan kemampuan mahasiswa dalam menulis berbahasa Inggris. Dari data temuan penelitia ini diketahui bahwa mahasiswa memiliki aktivitas menulis secara teratur dan perasaan senang. Kegiatan menulis dilanjutkan di rumah melalui forum diskusi facebook dengan jam diskusi yang telah disepakati. Sehingga proses penilaian sejawat sangat membantu. Mahasiswa yang memiliki kemampuan menulis lebih tinggi dapat membantu mahasiswa yang memiliki kemampuan menulis lebih 
rendah. Forum diskusi di facebook dapat meminimalisir rasa malu mahasiswa yang ingin bertanya ketika mengalami kesulitan menulis. Hal ini sangat membantu karena di kelas seringkali tidak mencukup untuk menyelesaikan tulisan dan dikoreksi dengan detail oleh rekan sejawat ataupun dosen. Facebook memfasilitasi kebutuhan tersebut. Beberapa penelitian yang telah berhasil menggunakan facebook untuk meningkatkan proses pembelajaran disimpulkan adanya dampak positif dari facebook terhadap peningkatan kemampuan menulis mahasiswa (Alias, Manan, Yusof, \& Pandian, 2012) dan sikap mahasiswa terhadap proses pembelajaran berubah (Alias et al., 2012). Hal sama telah ditemukan juga oleh Alias et al. (2012).

Temuan penelitian ini memberikan kontribusi terhadap perkembangan literatur untuk proses pembelajaran menulis. Mahasiswa memiliki perasaan lebih santai ketika dilakukan diskusi melalui facebook. Hal ini disebabkan karena mahasiswa bisa menggunakan bahasa informal juga, walaupun hal tersebut terjadi dalam forum diskusi, mahasiswa tetap fokus untuk memberikan timbal balik tulisan rekannya dengan menggunakan bahasa formal. Kondisi tersebut menjadi temuan baru dalam penelitian ini. Dari hasil wawancara dengan mahasiswa dan kolaborator diperoleh simpulan bahwa mereka mendapatkan manfaat dari penggunaan facebook karena secara langsung sering menerima informasi tambahan dan baru dari rekan-rekannya, dimana hal tersebut tidak terjadi di kelas. Hal ini terjadi karena dosen sebagai fasilitator diskusi di facebook mengatur dengan tepat. Sehingga proses diskusi tidak keluar dari kegiatan pembelajaran yang dilakukan di facebook.

Pembelajaran menulis di kelas yang dilanjutkan di luar kelas melalui media sosial memberikan kemudahan mahasiswa untuk selalu meningkatkan kemampuan menulis mereka. Pembelajaran menulis secara online memiliki prinsip yang cukup baik terhadap pemahaman pembelajaran, seperti yang dijabarkan dalam hasil kajian (Greer \& Harris, 
2018) bahwa prinsip-prinsip dasar rancangan pembelajaran yang berpusat pada pebelajar sangat baik dan bisa memodelkan proses umpan balik untuk mempromosikan pembelajaran secara online. Dengan demikian dapat dipahami bahwa teknologi melalui jaringan internet sangat menarik minat belajar mahasiswa, bahkan bagi anak-anakpun berpengaruh. İlter (2015) bahwa ada minat yang meningkat pesat dalam kebutuhan untuk menggunakan teknologi dalam pembelajaran bahasa pada usia dini. Pembelajar muda membutuhkan motivasi dan mereka dapat dengan mudah kehilangan konsentrasi selama proses pembelajaran bahasa yang panjang. Teknologi dapat menjadi salah satu cara untuk menciptakan suasana nyata dan menyenangkan bagi pelajar bahasa muda ketika digunakan dengan benar dan efektif. Teknologi digital, aplikasi, dan lingkungan belajar berbasis web telah digunakan untuk mengajar menulis pada tingkat sekolah menengah. Pembelajaran menulis yang dimediasi teknologi menghasilkan peningkatan dalam proses penyusunan tulisan dan keterampilan menulis serta pengetahuan dan penggunaan literasi baru. Siswa merancang, memproduksi, dan mempresentasikan berbagai teks multimoda dan digital yang mewakili pengetahuan dan pemahaman mereka tentang materi sastra dan masalah keadilan sosial kontemporer. Penggunaan teknologi memotivasi keterlibatan dan partisipasi siswa dalam tugas menulis dan meningkatkan interaksi sosial dan kolaborasi rekan (Williams \& Beam, 2019).

Di era saat ini sejumlah tantangan dihadapi oleh para pengajar dalam mengintegrasikan teknologi ke dalam kurikulum pembelajaran seperti pembelajaran menulis bahasa Inggris. Oleh karena itu, penelitian ini memberikan rekomendasi bahwa pengembangan profesionalitas pengajar dapat meningkatkan kualitas pembelajaran dalam penggunaan teknologi pedagogis. Karena kehidupan sekarang tidak dapat dipungkiri selalu terlibat dengan kemajuan teknologi. Saat ini proses pembelajaran dan pengajaran telah banyak memanfaatkan teknologi seperti media 
sosial untuk tujuan peningkatan kualitas pembelajaran.

\section{KESIMPULAN}

Dari hasil analisis data disimpulkan bahwa facebook memberikan dampak positif terhadap kemampuan menulis bahasa Inggris secara keseluruhan dan secara khusus untuk proses pembelajaran menulis deskriptif. Proses tanya-jawab berlangsung sangat aktif. Hal ini dapat dilihat pula dari hasil tes menulis deskriptif bahasa Inggris. Walaupun dosen memiliki pandangan berbeda dalam menggunakan facebook. Pembelajaran melalui facebook juga meningkatkan tata bahasa, kosa kata, dan berbagi pengetahuan mereka.

Temuan penelitian ini menunjukkan implikasi untuk praktik proses belajar mengajar di kelas dan di luar kelas dengan memanfaatkan kemajuan teknologi. Para dosen dapat memanfaatkan waktu di luar kelas selama 1 sampai 2 jam untuk diskusi di luar kelas melalui facebook.

\section{PENGAKUAN}

Peneliti menyampaikan rasa terima kasih kepada para mahasiswa semester II di Universitas Bina Sarana Informastika program studi Bahasa Inggris yang bersedia untuk melanjutkan proses belajar di luar kelas. Ucapan terima kasih juga disampaikan kepada rekan sejawat sebagai kolaborator yang memberikan penilaian terhadap pelaksanaan tindakan dalam penelitian ini.

\section{DAFTAR PUSTAKA}

Ahmad Zaki, A., \& Md Yunus, M. (2015). Potential of Mobile Learning in Teaching of ESL Academic Writing. English Language Teaching, 8(6), p11. https://doi.org/10.5539/elt.v8n6p11

Al-Hersh, A. H., \& Muflih, M. K. (2014). Attitudes of basic Stage Students towards the Use of Facebook in Arabic Language Writing. Procedia Social and Behavioral Sciences, 131, 140-143. https://doi.org/10.1016/J.SBSPR0.2014.04.093 
Alias, A. A., Manan, N. A. A., Yusof, J., \& Pandian, A. (2012). The use of Facebook as Language Learning Strategy (LLS) Training Tool on College Students' LLS use and Academic Writing Performance. Procedia - Social and Behavioral Sciences, 67, 36-48. https://doi.org/10.1016/J.SBSPR0.2012.11.305

Bicen, H., Sadıkoglu, S., \& Sadıkoglu, G. (2015). The Impact of Social Networks on Undergraduate Students Learning Foreign Language. Procedia - Social and Behavioral Sciences, 186, 1045-1049. https://doi.org/10.1016/J.SBSPR0.2015.04.072

Brandon, L., \& Brandon, K. (2011). Paragraphs and Essays With Integrated Readings Eleventh Edition. United State of America: Wadsworth,Cengage Learning.

Greer, M., \& Harris, H. S. (2018). User-Centered Design as a Foundation for Effective Online Writing Instruction. Computers and Composition, 49, 1424. https://doi.org/10.1016/J.COMPCOM.2018.05.006

İlter, B. G. (2015). How does Technology Affect Language Learning Process at an Early Age? Procedia - Social and Behavioral Sciences, 199, 311-316. https://doi.org/10.1016/J.SBSPR0.2015.07.552

Ponnudurai, P., \& Jacob, T. T. (2014). Facebook: A Shift from Social to Academia. Procedia - Social and Behavioral Sciences, 123, 122-129. https://doi.org/10.1016/J.SBSPRO.2014.01.1405

Putrawangsa, S., \& Hasanah, U. (2018). INTEGRASI TEKNOLOGI DIGITAL DALAM PEMBELAJARAN DI ERA INDUSTRI 4.0. Jurnal Tatsqif, 16(1), 4254. https://doi.org/10.20414/jtq.v16i1.203

Sabatino, L. (2014). Improving Writing Literacies through Digital Gaming Literacies: Facebook Gaming in the Composition Classroom. Computers and Composition, 32, 33. https://doi.org/10.1016/J.COMPCOM.2014.04.005

Sova, D. (2004). Writing Clearly A Self - Teaching Guide. United State of America: : John Wiley \& Sons.

Weigle, S. C. (2002). Assessing Writing. United Kingdom: Cambridge University Press.

Williams, C., \& Beam, S. (2019). Technology and writing: Review of research. Computers \& Education, 128, 227-242. https://doi.org/10.1016/J.COMPEDU.2018.09.024 